\title{
PENYULUHAN HUKUM TENTANG TATA CARA PERKAWINAN DAN PENTINGNYA PENCATATAN PERKAWINAN BERDASARKAN UNDANG-UNDANG NOMOR 1 TAHUN 1974
}

\author{
M. yazid fathoni ${ }^{*}$ ), Sahruddin, Diangsa Wagian \\ Fakultas Hukum Universitas Mataram \\ Jalan Mapahit Nomor 62 Mataram \\ ${ }^{*}$ Alamat Korespondensi : yazid233@gmail.com
}

\begin{abstract}
ABSTRAK
Walaupun telah di undangkan hampir selama 40 tahun, Undang-undang Nomor 1 Tahun 1974 masih saja asing bagi sebagian masyarakat. Hal ini dapat dilihat dari banyaknya perkawinan yang dilakukan hanya secara adat dan tidak menghiraukan ketentuan-ketentuan formal dalam Undang-undang Nomor 1 Tahun 1974, khususnya mengenai batas umur dan pencatatan perkawinan. Akibatnya lebih jauh, mereka kesulitan ketika akan menghadapi berbagai urusan yang bersinggungan dengan hal-hal yang bersifat administratif, seperti pembuatan akta kelahiran anak dan lainnya. Di lokasi yang akan dijadikan penyuluhan ditemukan selain banyak terjadi pernikahan sirri juga banyak terjadi pernikahan di bawah umur, yang rata -rata dilakukan pada usia Sekolah Menengah Atas. Umumnya yang melakukan pernikahan dibawah umur ini di lokasi penyuluhan adalah perempuan. Tujuan kegiatan ini adalah memberikan keterampilan dalam mehami subtansi dan administrasi pencatatan perkawinan. Kegiatan ini menghasilkan pemahaman, penguasaan, dan keterampilan pengurusan administrasi perkawinan untuk mendapatkan keabsahan perkawinan. Kesimpulan dari kegiatan ini kesadaran hukum masyarakat sangat kurang sehingga upaya peningkatan ke arah itu perlu ditingkatkan.
\end{abstract}

Kata kuci: Undang-undang Nomor 1 Tahun 1974, pencatatan perkawinan

\section{PENDAHULUAN}

Peningkatan pengatahuan dan pemahaman masyarakat tentang hukum perkawinan menurut Undangundang Nomor 1 Tahun 1974 menarik untuk dijadikan tema dalam suatu penyuluhan hukum. Seperti diketahui, Indonesia merupakan negara yang memillki karakteristik masyarakat yang plural, baik dari sabang sampai mereuke. Tiap-tiap daerah mempunyai tata cara, adat istiadat, budaya, kesenian, kepercayaan, nilai, dan agama yang berbeda. Kemajemukan masyarakat tersebut ternyata berimplikasi terhadap berbagai hal, 
tidak terkecuali hukum dan cara berhukum tiap-tiap masyarakat tersebut. Namun demikian sejak zaman kolonial belanda sampai dengan zaman kemerdekaan indonesia, pihak penguasa tidak hentihentinya mencari bentuk dan cara untuk menyatukan perbedaan hukum tersebut, salah satunya dengan mecari asas kesamaannya dalam sebuah aturan positif yang dapat berlaku bagi seluruh rakyat indonesia.

Undang-undang Nomor 1

Tahun 1974 merupakan salah satu undang-undang atau aturan positif yang mencoba melakukan hal seperti yang dijelaskan di atas. Undangundang Nomor 1 Tahun 1974 merupakan undang-undang pertama setelah indonesia merdeka yang mengatur masalah perkawinan. Keberadaan undang-undang ini tidak lepas dari politik hukum pemerintah yang mencoba untuk mengatasi pluralisme hukum di indonesia, khususnya mengenai hukum perkawinan. Seperti diketahui bahwa sebelum Undang-undang Nomor 1 Tahun 1974 setidaknya ada beberapa aturan hukum yang mengatur masalah perkawinan di indonesia yakni: Bagi orang-orang indonesia Asli yang beragama Islam berlaku hukum agama yang telah diresipiir dalam Hukum Adat; bagi orang-orang Indonesia Asli lainnya berlaku Hukum Adat; bagi orang-orang Indonesia Asli yang beragama Kristen berlaku Ordonantie Christen Indonesia (S. 1933 Nomor 74); bagi Orang Timur Asing Cina berlaku ketentuan Kitab Undang-undang Hukum Perdata dengan sedikit perubahan; bagi orang-orang Timur Asing lain-lainnya dan warganegara Indonesia keturunan Timur Asing lainnya tersebut berlaku Hukum Adat mereka; bagi orang-orang Eropa dan yang disamakan dengan mereka berlaku Kitab Undang-undang Hukum Perdata.

Walaupun telah di undangkan hampir selama 40 tahun, Undangundang Nomor 1 Tahun 1974 masih saja asing bagi sebagian masyarakat. Hal ini dapat dilihat dari banyaknya perkawinan yang dilakukan hanya secara adat dan tidak menghiraukan ketentuan-ketentuan formal dalam Undang-undang Nomor 1 Tahun 1974, khususnya mengenai batas umur para 
pihak yang melakukan perkawinan. Akibatnya lebih jauh, mereka kesulitan ketika akan menghadapi berbagai urusan yang bersinggungan dengan hal-hal yang bersifat administratif, seperti pembuatan akta kelahiran anak dan lainnya. Kondisi ini ternyata didukung oleh pengetahuan masyarakat mengenai ketidakjelasan dasar, kedudukan, mekanisme, dan akibat hukum bagi masyarakat jika tidak mengikuti ketentuan formal dalam Undang-undang Nomor 1 Tahun 1974, tidak terkecuali di lokasi yang akan dijadikan rencana tempat kegiatan (penyuluhan) ini. Hal ini terbukti dengan masih banyaknya terjadi pernikahan siri dan pernikahan di bawah umur.

Dengan demikian masalah peningkatan pemahaman masyarakat terhadap hukum perkawinan dan pentingnya pencatatan perkawinan sangat perlu dilakukan dalam berbagai bentuk, tidak terkecuali dengan cara penyuluhan. Hal ini perlu dilakukan, mengingat minimnya pengetahuan dan banyaknya perkawinan dibawah umur, tanpa menghiraukan ketentuan peraturan perundang-undangan di masyarakat.

Tujuan dari penyuluhan ini adalah untuk meningkatkan pemahaman masyarakat mengenai norma-norma yang ada dalam Undang-undang Nomor 1 Tahun 1974 tentang Perkawinan. Secara lebih rinci tujuan dan manfaat yang ingin diraih dalam kegiatan ini antara lain sebagai wujud pelaksanaa Tri Dharma Perguruan Tinggi. Sedangkan manfaat kegiatan penyuluhan ini adalah agar mengetahui apa yang menjadi dasardasar hukum perkawinan menurut Undang-undang 1 Tahun 1974 dan masyarakat mengetahui hal-hal apa yang harus dilakukan jika akan melakukan perkawinan. Ataupun, jika ada salah satu dari keluarganya akan melakukan perkawinan maka mereka bisa memberikan petunjuk menganai hal-hal yang akan dilakukan agar sesuai dengan ketentuan Undangundang Nomor 1 Tahun 1974.

Permasalahan dan Solusi Yang ditawarkan

Perkawinan yang dilakukan oleh masyarakat pada saat ini banyak dilakukan diluar yang ditentukan oleh negara atau di luar yang ditentukan 
oleh Undang-undang Nomor 1 Tahun 1974, akibatnya perkawinan yang mereka lakukan tidak mempunyai akibat hukum. Hal ini tentunya sangat merugikan para pihak, terutama bagi pihak perempuan dan anak karena tidak memiliki ketidak jelasan status dan kedudukan dalam keluarga. Bagi pihak perempuan, sebagai contoh, ketika akan melakukan perceraian maka akan timbul ketidak jelasan terhadap harta bersamanya; sedangkan bagi anak, sebagai contoh, akan sulit mendapatkan akta kelahiran karena ketidakjelasan status perkawinan orang tuanya.

Dari identifikasi permasalahan tersebut maka sangat diperlukan suatu penyuluhan masyarakat terkait dengan tentang tata cara perkawinan dan pentingnya pencatatan perkawinan berdasarkan Undangundang Nomor 1 Tahun 1974.

\section{METODE KEGIATAN}

Metode Kegiatan dalam penyuluhan ini adalah ceramah dan diskusi. Ceramah yakni penyampaian materi melalui metode pemaparan yang dilakukan oleh tim penyuluh kepada peserta, sehingga para peserta dapat mengetahui tentang materi penyuluhan yang disampaikan oleh penyuluh. Sedangkan diskusi dan tanya jawab yakni dengan memberikan kesempatan kepada para peserta untuk mengajukan pertanyaan ataupun pendapatnya perihal materi yang disampaikan sehinga dapat menjadi masukan dan menambah wawasan pemahaman terhadap materi yang disampaikan oleh tim penyuluh

\section{Kerangka Pemecahan Masalah} Pemecahan masalah dengan cara memberikan informasi dan pemahaman yang benar kepada masyarakat tentang tentang dasardasar Hukum Perkawinan menurut Undang-Undang Nomor 1 Tahun 1974. Kemudian setelah masyarakat mengetahui dasar perkawinan tersebut, langkah berikutnya adalah memberikan pemahaman mengenai hubungan hukum yang terjadi dan akibat hukumnya terhadap para pihak, baik pihak suami, istri maupun anak. Akhirnya dengan pemahaman tersebut diharapkan masing-masing pihak dapat memahami hak dan 
kewajibannya dalam keluarga menurut Undang-undang Nomor 1 Tahun 1974 Komponen masyarakat yang akan menjadi sasaran kegiatan penyuluhan ini adalah masyarakat disekitarnya, terutama masyarakat yang belum pernah melangsungkan perkawinan seperti remaja-remaja yang masih dibangku sekolah menengah atas .

\section{HASIL KEGIATAN}

Setelah kegiatan penyuluhan yang kami laksanakan di Desa Langko Kecamatan Janapria Kabupaten Lombok Tengah, kami berpendapat bahwa materi dalam penyuluhan perlu lebih ditingkatkan, sebab dari diskusi dan tanya jawab saat penyuluhan berlangsung antara masyarakat dan pemberi materi mengenai perkawinan sirri dan perkawinan di bawah umur menurut Undang-undang Nomor 1 Tahun 1974, mereka sangat antusias. Hal ini dapat dilihat dari banyaknya peserta yang hadir dan banyaknya pertanyaan yang ingin disampaikan kepada pemateri.

Seperti telah dijelaskan sebelumnya bahwa masyarakat yang ada di Desa Langko Kecamatan Janapria Kabupaten Lombok Tengah sangat antusias dengan adanya penyuluhan hukum tentang "Perkawinan Dibawah Umur Dan Akibat Hukumnya Terhadap Status Anak Yang Dilahirkan" yang memang sangat diperlukan oleh masyarakat setempat. Masyarakat Langko sangat memerlukan penyuluhan semacam ini karena kekurangpahaman mereka tentang hukum perkawinan yang berlaku di Indonesia. Selama ini sebagian dari mereka melaksanakan perkawinan hanya berlandaskan pada ketentuan-ketentuan hukum agama, khususnya islam dan kepada tradisitradisi yang mengakar pada masyarakat sasak, tanpa tahu hukum positif yang berlaku di Indonesia dan akibat hukumnya bagi mereka yang melangsungkan perkawinan, ksususnya terkait dengan perkawinan dini dan anak yang dilahirkan.

Akibatnya, karena mereka melandaskan pernikahan mereka pada ketentuan hukum yang berkembang di masyarakat dan mengabaikan ketentuan hukum negara maka mereka kesulitan ketika 
akan berhadapan dengan hal-hal yang bersifat administratif dari negara. Salah satu contohnya adalah jika pernikahan dilakukan tanpa hukum negara maka akibat lebih lanjutnya adalah tidak dapat dihasilkannya akta nikah sebagai alat bukti telah terjadi pernikahan antara para pihak tersebut. Konsekuensi lebih lanjutnya adalah jika pernikahan tersebut menghasilkan anak maka hubungan anak hanya akan mempunyai hubungan dengan ibunya saja, karena pernikahannya tidak dianggap ada oleh negara. Selain itu, karena perkawinan dilakukan di luar ketentuan hukum perkawinan yang berlaku, maka tidak ada juga tersedia upaya hukum pencegahan dan pembatalan perkawinan bagi pihakpihak yang memerlukannya.

Dalam penyuluhan

hukum yang berlangsung di Desa Langko Kecamatan Janapria Kabupaten Lombok Tengah, para peserta banyak mempertanyakan cara pernikahan yang benar dan batasan umur dalam suatu pernikahan, sesuai dengan ketentuan yang ditetapkan oleh negara. Hal ini dipertanyakan sebab mereka menginginkan suatu kejelasan mengenai mekanisme yang benar dalam melakukan pernikahan dan batasan umurnya sehingga dapat menimbulkan akibat hukum seperti yang diharapkan. Merekapun mempertanyakan mengenai langkahlangkah apa saja yang dapat ditempuh oleh para pihak atau masyarakat jika mereka terlanjur telah melakukan pernikahan di luar ketentuan dan batasan umur yang ditetapkan oleh negara, bagaimana cara mendapatkan pengakuan, bagaimana cara mendapatkan akta nikah, dan lain sebagainya. Tidak lupa, merekapun mempertanyakan proses dari upayaupaya hukum pencegahan dan pembatalan perkawinan di dalam Undang-undang Nomor 1 Tahun 1974 sebagai suatu sebab yang dapat menghalangi atau memutuskan perkawinan.

Akhirnya para peserta penyuluhan hukum meminta tidak saja kepada tim penyuluh untuk tetap melakukan hal-hal seperti ini, akan tetapi seharusnya pihak pemerintahpun lebih aktif untuk mencari cara agar masyarakat 
mengatahui ketentuan-ketentuan yang telah ditetapkan negara.

Dalam pelaksanaan kegiatan penyuluhan hukum ini tim penyuluh tidak mengalami hambatan-hambatan atau kendala-kendala yang berarti, sehingga pelaksanaan pesnyuluhan berjalan dengan baik dan memuaskan. Hal ini ditandai dengan adanya keinginan dari peserta penyuluhan hukum untuk lebih memperdalam pemahaman mereka lebih lanjut mengenai hukum perkawinan menurut Undang-undang Nomor 1 Tahun 1974. Harapan mereka kegiatan-kegiatan seperti ini dapat dilanjutkan dikemudian hari.

Adapun materi-materi yang disampaikan dalam penyuluhan ini adalah dimulai dari pengertian perkawinan dalam Undang-Undang Nomor 1 Tahun 1974.

Dalam Pasal 1 Undang-undang Nomor 1 Tahun 1974 memberikan defenisi perkawinan sebagai berikut: "Perkawinan ialah ikatan lahir batin antara seorang pria dengan seorang wanita sebagai suami istri dengan tujuan membentuk keluarga (rumah tangga) yang bahagia dan kekal berdasarkan Ketuhanan Yang Maha Esa".

Sedangkan tujuan Perkawinan adalah membentuk keluarga (rumah tangga) yang bahagia dan kekal. Yang dimaksud keluarga disini adalah suatu kesatuan yang terdiri dari ayah, ibu dan anak atau anak-anak yang merupakan sendi dasar sususnan masyarakat Indonesia (Hamijojo, 2006).

Syarat Sahnya Perkawinan Menurut Undang-Undang Nomor 1 Tahun 1974 tentang Perkawinan

Kapankah ikatan atau persekutuan antara seorang pria dengan seorang wanita dalam dipandang sebagai suami istri? Yaitu bilamana ikatan mereka di dasarkan pada perkawinan yang sah. Suatu perkawinan adalah sah, bilamana memenuhi syarat-syarat yang ditentukan oleh undang-undang, baik syarat internnya maupun syarat externnya. Yang dimaksud dengan syarat-syarat intern adalah yang menyangkut pihak-pihak yang melakukan perkawinan yaiu: kesepakatan mereka, kecakapan dan juga adanya izin dari pihak lain yang harus diberikan untuk melangsungkan 
perkawinan. Sedangkan syarat extern adalah yang menyangkut formalitasformalitas dalam melangsungkan perkawinan.

Syarat-syarat intern untuk melangsungkan perkawinan:

1. Perkawinan harus didasarkan atas persetujuan kedua belah pihak;

2. Harus mendapat izin dari kedua orang tua, bilamana masingmasing calon belum mencapai umur 21 tahun;

3. Bagi pria harus sudah mencapai usia 19 tahun dan wanita 16 tahun, kecuali ada dispensasi yang diberikan oleh pengadilan atau pejabat lain yang ditunjuk oleh kedua belah pihak;

4. Bahwa kedua belah pihak dalam keadaan tidak kawin, kecuali bagi mereka yang agamanya mengizinkan untuk berpoligami;

5. Bagi seorang wanita yang akan melakukan perkawinan untuk kedua kali dan seterusnya, undangundang mensyaratkan setelah lewatnya masa tunggu, yaitu sekurang-kurangnya 90 hari bagi yang putus perkawinannya karena perceraian, 130 hari bagi mereka yang putus perkawinannya karena kematian suaminya.

Syarat-syarat extern untuk pelangsungan perkawinan:

1. Laporan;

2. Pengumuman

3. Pencegahan

4. Pelangsungan

Perkawinan itu terikat pada bentuk tertentu, yaitu harus dilakukan di hadapan pejabat yang ditunjuk oleh negara. Setiap orang yang akan melangsungkan perkawinannya diwajibkan untuk memberitahukan kehendaknya itu kepada pegawai pencatat perkawinan di tempat perkawinan akan dilangsungkan yang harus dilakukan sepuluh hari kerja sebelum perkawinan dilangsungkan (Pasal 3 PP 9/1975). Pemberitahuan dapat dilakukan secara lisan maupun tertulis yang dapat dilakukan oleh calon mempelai atau oleh orang tua atau wali mereka (Pasal 4 PP 69 Tahun 1975). Atas pemeberitahuan ini, maka pegawai pencatat yang menerima pemmberiatahuan wajib meneliti apakah syarat-syarat perkawinan bagi yang bersangkutan telah dipenuhi secara lengkap, yaitu sesuai dengan 
syarat-syarat yang ditentukan oleh pasal 6 PP 9 Tahun 1975.(R. SoetojoPrawiro Hamidjojo, 2006).

Pencatatan Perkawinan

Masalah

Pencatatan

perkawinan di indonesia diatur dalam beberapa pasal peraturan perundangundangan berikut ini. Pasal 2 ayat (2) Undang-undang Nomor 1 Tahun 1974 mengatur: "Tiap-tiap perkawinan dicatat menurut peraturan perundangundangan yang berlaku." (Hadiwardoyo, 1990). Pencatatan dilakukan oleh Pegawai Pencatat Nikah (PPN) sebagaimana yang dimaksud oleh Undang-undang Nomor 32 Tahun 1954 tentang Pencatatan Nikah, Talak, dan Rujuk. Sedangkan tata cara pencatatannya berpedoman kepada ketentuan Perturan Pemerintah Nomor 9 Tahun 1975. Selanjutnya, Pasal 10 Ayat (3) Peraturan Pemerintah Nomor 9 Tahun 1975 menentukan bahwa perkawinan dilaksanakan di hadapan Pegawai Pencatat yang dihadiri oleh dua orang saksi. Fungsi pencatatan di jelaskan dalam penjelasan Undang-undang Nomor 1 Tahuun 1974: Pencatatan tiap-tiap perkawinan adalah sama halnya dengan pencatatan peristiwaperistiwa penting dalam kehidupan seseorrang, misalnya kelahiran, kematian yang dinyatakan dalam surat-surat keterangan, suatu akta yang juga dimuat dalam daftar pencatatan.

Perintah tersebut sungguh ditujukan untuk segenap warga negara Indonesia, apakah ia berada di wilayah indonesia maupun berada di luar negeri. Bagi warga negara Indonesia yang melangsungkan perkawinannya di luar indonesiapun diatur dengan ketentuan yang terdapat dalam Pasal 56 Undang-undang Nomor 1 Tahun 1974 : Perkawinan yang dilangsungkan di luar Indonesia antara dua orang warga negara Indonesia atau seorang warga negara Indonesia dengan warga negara asing adalah sah bilamana dilakukan menurut hukum yang berlaku di negara dimana perkawinan itu dilangsungkan dan bagi warga negara Indonesia tidak melanggar ketentuan undang-undang ini. Dalam waktu satu tahun setelah suami istri itu kembali ke wilayah Indonesia surat bukti perkawinan mereka harus di daftarkan di Kantor 
Pencatatan Perkawinan tempat bukan agama Islam pencatat tinggal mereka

Peraturan Pemerintah Nomor perkawinannya dilakukan di kantor Catatan Sipil. (Ansyary, 2009).

9 tahun 1975 mengatur perkawinan harus dilaksanakan di hadapan Pegawai Pencatat yang dihadiri oleh dua orang saksi. Sesaat sesudah perkawinan dilangsungkan, kedua mempelai menandatangani akta perkawinan yang telah disiapkan oleh Pegawai Pencatat tersebut. Dengan penandatanganan akta perkawinan tersebut, perkawinan tersebut telah tercatat secara resmi. Selanjutnya, kepada masing-masing suami istri diberikan kutipan akta perkawinan tersebut. Dengan diperolehnya kutipan akta perkawinan itu perkawinan mereka telah dinyatakan sebagai perkawinan yang mempunyai hak mendapat pengakuan dan perlindungan hukum.

Perintah undang-undang untuk mencatatkan perkawinan berlaku juga sebagai bangsa Indonesia yang beragama Islam, hanya saja bedanya bahwa pencatatan perkawinan bagi Umat Islam dilakukan di Kantor Urusan gama Kecamatan, sedangkan bagi bangsa Indonesia yang beragama

\section{KESIMPULAN DAN SARAN}

Berdasarkan uraian-uraian di atas, maka dapat ditarik suatu kesimpulan sebagai berikut:

1. Penyuluhan hukum tentang tata cara perkawinan dan pentingnya pencatatan perkawinan berdasarkan Undang - Undang Nomor 1 Tahun 1974. Hal ini karena pernikahan ditempat yang dijadikan lokasi penyuluhan sering terjadi pernikahan sirri dan pernikahan dibawah umur. Para pihak terkait dengan perkawinan, baik pihak yang akan melangsungkan perkawinan, pengampu, wali, maupun keluarga lainnya belum banyak yang memahami ketentuan-ketentuan dalam Undang-undang Nomor 1 Tahun 1974.

2. Penyuluhan hukum ini pada dasarnya merupakan salah satu upaya untuk meningkatkan pengatahuan dan pemahaman masyarakat terhadap hukum yang 
berlaku di Indonesia. Harapannya kedepan, para peserta akan menjadi masyarakat sadar hukum, artinya masyarakat yang memahami dan melaksanakan hukum yang berlaku di indonesia, hal ini sesuai dengan program pemerintah selama ini.

3. Karena penyuluhan ini dilakukan dengan kerjasama Desa dan Yayasan, maka guru-guru yang berada di yayasan ini akan melanjutkan upaya pemahaman tentang ketentuan dalam UndangUndang Nomor 1 Tahun 1974, selain itu mereka berjanji akan melakukan upaya pencegahan pernikahan dini dimulai dari para santri yang berada di Yayasan.

Saran yang dapat diberikan dari pelaksanaan kegiatan pengabdian kepada masarakat ini adalah:

1. Perlunya penyadaran masyarakat tentang pentingnya pengetahuan dan pemahaman masyarakat tentang hukum perkawinan menurut Undang-undang Nomor 1 Tahun 1974. Hal ini untuk tetap memberikan pemahaman kepada masyarakat mengenai proses perkawinan yang benar beserta akibat hukumnya kepada para pihak.

2. Peran KUA bagi masyarakat muslim dan Catatan Sipil bagi yang nonmuslim perlu ditingkatkan, bukan hanya melaksanakan ketentuan dibidang perkawinan secara formal, akan tetapi ikut aktif memeberikan penyadaran terhadap masyarakat pentingnya keabsahan suatu perkawinan.

\section{UCAPAN TERIMAKASIH}

Terselenggaranya kegiatan pengabdian masyarakat di Desa Langko Kecamatan Janapria ini tidak lepas dari dukungan pihak Universitas Mataram dalam mendukung setiap program Tridarma Perguruan Tinggi. Khusus untuk program yang dilakukan di Desa Langko Kecamatan Janapria, kami mendapatkan dukungan dana dari Universitas Mataram melalui dana BOPTN.

Selain itu, kami juga mengucapkan terimakasih Yayasan Yayasan Al-Muhamady yang telah menyediakan tempat dan membantu kami mengumpulkan para remaja yang 
akan memasuki usia perkawinan.

Ucapan terimakasih tidak lupa kami

haturkan kepada Bapak Pimpinan

yayasan yang telah meluangkan

waktunya memberikan kata sambutan

dan sekaligus membuka acara

penyuluhan hukum ini.

\section{DAFTAR PUSTAKA}

H.M. Ansyary MK, 2009, Hukum

Perkawinan Di Indonesia

(Masaalah-maslah Krusial),

Yogyakarta, Pustaka Pelajar
Peraturan Pemerintah Nomor 9 Tahun

1975 tentang Pelaksanaan

Undang-undang Nomor 1

Tahun 1974 tentang

Perkawinan

R. SoetojoPrawiro Hamidjojo, 2006,

Pluralisme Dalam Perundang-

undangan Perkawinan Di

Indonesia, Surabaya, Airlangga

University Pres, Cetakan

keempat, 2006

Undang-undang Nomor 1 Tahun 1974

tentang Perkawinan

Undang-undang Nomor 32 Tahun

1954 tentang Pencatatan

Nikah, Talak, dan Rujuk 